\title{
How to Restore Forest Areas in a Smallholder Agriculture-Dominated Country?
}

\author{
Sangaré Moussa ${ }^{1}$ \\ ${ }^{1}$ Alassane Ouattara University (UAO), Bouaké, Côte d'Ivoire \\ Correspondence: Sangaré Moussa, Alassane Ouattara University (UAO), Bouaké, Côte d'Ivoire. E-mail: \\ sangaremou@yahoo.fr
}

Received: December 19, 2016 Accepted: January 5, 2017 Online Published: January 25, 2017

doi:10.5539/jms.v7n1p40 URL: http://dx.doi.org/10.5539/jms.v7n1p40

\begin{abstract}
This study deals with ways of addressing more effectively the problems of forest restoration in a smallholder agriculture-dominated area like the southwest Côte d'Ivoire. An empirical estimation based on a probit model is used to analyze the farmer decisions concerning their eventual participation to the national program of forest development based on a policy of large-scale reforestation.

The results show that the main explicative variables of smallholders' adhesion to this project are agricultural training, ethnic group, access to credit, the age of the head of household and the household's residence area. Contrary to all expectations, some variables such as literacy, out-farm income, and the status of landowner and whole-time farmer do not explain the decision of smallholder.
\end{abstract}

Keywords: Côte d'Ivoire, forest management, probit model

\section{Introduction}

In Côte d'Ivoire, forest degradation is alarming. Indeed, forest area has shrunk from 12 million hectares in 1960 to nearly 2.8 million hectares nowadays. During this period, forests were disappearing at the average rate of 300000 hectares per annum. And it is roughly estimated that about three-quarters of Ivorian forest cover was lost. Côte d'Ivoire has also one of the highest rates of deforestation in Sub-Saharan Africa driven mainly by an extensive agriculture and a great commercial logging (Sangaré, 2014; FAO, 2012; Ministry of Planning and Development, 2012; Ehui \& Hertel, 1989).

As most of African countries, Côte d'Ivoire is widely based on agriculture which represents on average $27 \%$ of Gross Domestic Product, $60 \%$ of national export revenues and employs about $60 \%$ of labor force (Ministry of Planning and Development, op. cit.). This country has known a high agricultural growth rate (nearly $5 \%$ per year) during two decades 1960-1980 (Ehui \& Hertel, op. cit.). Côte d'Ivoire's principal agricultural export crops are cocoa, coffee, wood and rubber. This country is the leading global cocoa producer, responsible for $40 \%$ of world output. Cocoa represents its main export crop with $40 \%$ of national export revenues, $10 \%$ of Gross Domestic Product, and nearly 600,000 growers that provide food and shelter to about 6 million persons (Tano, 2012). As per 2014 census, more than half (nearly 50.3\%) of Côte d'Ivoire's inhabitants continue to live in rural areas where agriculture is the main source of livelihoods (Ministry of Planning and Development, 2014). The high rate of deforestation and the agricultural performance of Ivorian economy highlight clearly the plight of forest resources, and call attention to the problem of optimal restoration of forest land.

In reviewing the studies on deforestation and agriculture in Côte d'Ivoire since 1960s, the most interesting question is not, what did the agriculture contribute to the deforestation, but rather, how does this latter constrain the first and how is it able today to stop or restrain this phenomenon of deforestation? Henceforth, the studies on deforestation, as it has been aptly remarked in several previous studies (see Sangaré, 2014), should focus on the social and economic consequences of forest depletion, particularly in the densely populated rural areas.

Among the most important challenges facing Ivorian authorities, there is the task of identifying development strategies of agriculture that can simultaneously preserve forest areas, increase agricultural production, generate income opportunities, and reduce the frequent penuries of foodstuffs on the market. As a whole, these challenges could be attained if only the agricultural productivity and food supply of Ivorian cities are noticeably improved (Stessens \& Dao, 2006; Ehui, Hertel, \& Preckel, 1990; Ehui \& Hertel, 1989). 
Besides, Ivorian authorities had foreseen the increase of forest area from $14 \%$ in the decade 2000 to $20 \%$ (nearly 6.45 million hectares) of land area on the horizon 2015 through a large-scale reforestation. Even if it seems unlikely in the foreseeable future, this objective should allow later the preservation of rural landscape and rural goods and services (Ministry of Planning and Development, op. cit.). Elsewhere, this policy should exacerbate the pressure on the farmers, particularly the smallholders, which are forced to diversify their income sources to maintain their standard of living. In presage to these events, it is important firstly to assess the extent of forest depletion and secondly to estimate the adhesion of farmers to the policy of forest restoration. Nevertheless, only a few studies have investigated these issues in the context of today's African countries and mainly Ivorian economy.

To our knowledge, this paper represents one of the first efforts to fill this gap by identifying and measuring the impacts of socio-demographic, economic and environmental characteristics associated with the acceptance of the project of forest restoration in Côte d'Ivoire. The present study would like to shed light on the next questions.

For national program of forest development to be viable, the key issue is whether growers would be willing to assign a part of their parcel to allow the reconstitution of forest areas without a major damage for their agricultural production. Will farmers be able to diversify their crop choices toward timber culture which is a high-value crop? In other words, the adoption of the teak cultivation is it an optimal strategy of the diversification of farm incomes? The other next issues of this study are the following items. Have the farmers been worried by forest resources depletion? Do the status of landowner or out-farm income opportunities influence the decision of the farmers to participate to the restoration of forest resources?

The aim of this study is to provide policy-makers with answers to these questions and offer a richer insight into the role of social, cultural and economic factors in explaining farmers' adhesion to the reforestation policy. This study analyzes these issues in depth by outlining a theoretical framework and a conceptual model deeply inspired from models of choice.

The paper is organized as follows. The next section provides an overview of literature. Section 3 describes the methodology of the study. In section 4, the results of the econometric analysis are reported and discussed. Section 5 presents some concluding remarks.

\section{Literature Review}

In spite of the widespread concern about deforestation in Côte d'Ivoire (Sangaré, 2014; Djézou, 2010; Sylla, 1999; Coulibaly, 1998; Ehui \& Hertel, 1989), few empirical studies analyzed the determinants of reforestation. Nonetheless, to our knowledge, only two studies (Wasikama, 1998; Sangaré, 2017) analyzed the adhesion of populations to any project of reforestation in this country. By using the contingent valuation method, these studies have analyzed the behavior of the tourists for the one and of the farmers for the second. Yet, elsewhere in the world, some studies attempted this type of reasoning.

Westerberg et al. (2010) offer insight into public preferences over the range of possible future landscape configurations for the Marais des Baux wetland in southern France. To attain this objective, the authors use a random parameter logit model by taking account of unobserved and observed preference heterogeneity. In their study, these authors reveal that the demand for a high level of biodiversity is conditional on respondents expressing a high level of environmental concern, and that parenthood raises the willingness-to-pay for any future management alternative different from the current situation. Further, they find that mosquito control or attachment to the area is essential for support of large-scale wetland restoration. From the perspective of maximising the compensating surplus, they recommend the restoration of the wetland to one third of its original size in conjunction with biological control of mosquitoes, more tree hedgerows and recreational facilities, while increasing efforts to induce higher levels of biodiversity.

In order to take account not only for the private benefits to forest landowners but also for the ecological, environmental and economic benefits valued by society, Madureira et al. (2011) attempt to assess a best alternative management strategy for a forest area in Central Portugal by implementing a contingent valuation experiment where an advanced landscape visualisation technique is employed to generate the visual information conveyed in the valuation scenarios. Then, several econometric model specifications are considered as well as alternative approaches to handle zero willingness to pay values and protest responses. The results obtained suggest that there is a willingness-to-pay landowners for the amenities their forests may provide. Around $75 \%$ of the respondents would support programs funding adequate forest management by landowners. The variable AGE exhibits a negative impact on willingness to pay (WTP) for both strategies.

With consumer survey data, collected in former West and East Berlin after the unification of Germany, Moon et al. (2002) analyze the issue of WTP for foods produced with techniques consistent with environmental 
stewardship. The main result of this study reveals some differences in the WTP between residents of the two former German states attributed to area of residence. Also, with respect to the effect of city administrative district, these authors find that consumers residing in the former West Berlin were more willing to pay a premium than those who were living in the former East Berlin. Besides, younger respondents were found to be more willing to pay a premium for agricultural products produced with environmentally sound practices. Contrary to all expectations, education was found to be insignificant in consumer valuation of agricultural products produced with environmentally benign techniques. The authors explain this situation by the fact that respondents with higher education may be more aware of environmental problems attributable to nonagricultural sources whereas considering agriculture itself as an insignificant source of environmental degradation. This study shows that household income did not have statistically significant effects on the WTP for environmentally sound agricultural practices. Higher-income respondents were not willing to pay more than lower-income respondents.

Lera-López et al. (2012) examine the willingness-to-pay of people living in a number of villages in Navarre, in the Spanish Pyrenees to reduce noise and air pollution. These authors use several models based on contingent valuation. They find that those living near roads are willing to pay more to reduce air and noise pollution. In addition, younger people, the better educated, and the more environmentally aware individuals are also willing to pay more to reduce those externalities.

A study by Wasikama (1998), based on a sample of 212 tourists, discusses the rationality of the preservation of National Park of Taï by comparing this option with the others possible alternative in land uses. By using a financial analysis, the author assesses the net present value of NPT to about 366 billion CFA francs. Also, the economic analysis of Wasikama's study, based on the contingent valuation method, allowed identifying the main explicative variables of willingness-to-pay of tourists for the preservation of NPT. Thus the author proceeded with two estimates: a logit model and a semi-log model. The results of two models show that the variable age contributes to explain the WTP of the tourists surveyed.

Sangare (2017) analyzed the determinants of the willingness-to-accept of the smallholders for the restoration of National Park of Taï. By using the contingent valuation method, this author described the smallholders' attitudes, which are settled in the south-west Côte d'Ivoire, towards the forest resources. The aim of this study is to assess the amount that the smallholders could accept as compensation for the cession of a part or a whole of their cultivated land areas to Ivorian state in order to preserve the National Park of Taï. The statistical and econometrical analyses reveal that only few farmers would accept to adhere to the project. The results of Sangaré's study allow also identifying the educational attainment, the part-time farming practice, the membership in support group, the experience in farming, the environmental characteristic of residence area, the farm-home distance and the environmental sensitivity of the individual like the main determinants of the willingness to accept (WTA) of the farmers settled in the vicinity of NPT.

\section{Methodology}

In order to understand the decisions of the farmers about their participation or not to the policy of forest restoration, it is possible to resort to the models of choice to conduct the analysis. Among the available models of choice, a model seems emerged and outclasses the others models. Indeed, probit model is recognized as one of the best quantitative techniques and tools for the analysis of the questions of choice since a long time.

The Probit models are used to model a relationship between a dependent variable Y and one or more independent variables $\mathrm{X}$. In these models, the dependent variables are discrete variables that represent a choice or category from a set of mutually exclusive choices or categories. The independent variables could be discrete variables as well as continuous variables.

\subsection{Study Area, Questionnaire design and Data Collection}

Until the mid-1960s, the south-west area had the lowest density of population ( 2 inhabitants per kilometer-square). But with the building of several economic infrastructures (the Port of San Pedro, the dam of Buyo, several logging units, the bridge of Soubré (on Sassandra river)) and the war of Liberia, a massive influx of population has been observed for some time past. Today, the percentage of native people, Krou ethnic group, is fewer than $10 \%$ of population. Thus the density of population has been increased from 25 inhabitants per $\mathrm{km}$-square in 1965 to 40 inhabitants per km-square in 1995 (OIPR, 2006).

In south-west Côte d'Ivoire, the population rose to 1912876 inhabitants in 2008 from 647696 inhabitants in 1988. Today, this region represents one of the most densely populated rural areas of the country; and it has been chosen as study area for three main reasons: firstly it will shelter about $10 \%$ of Ivorian population (i.e., nearly 2839736 inhabitants) on the horizon 2020. Secondly, most of those inhabitants will continue to practice agriculture like their main income-generating activities. Thirdly, the remaining forest areas are mainly located in 
this region where large populations of rural people live near forests under state control and depend on them for subsistence and, sometimes, for commercial purposes. For these reasons, there is justification in giving to this study a particular attention in national program of forest conservation.

Agriculture and its connected activities form the backbone of the economy of the south-west Côte d'Ivoire. This agriculture is dominated by cash crops (cocoa, coffee, rubber, palm tree, etc.). Unfortunately, agricultural yield is on the wane. It is equivalent to 200 kilograms per hectare for cocoa culture in this region against 500 kilograms per hectare at national level (OIPR, 2006). However, cocoa production of this region, which represents nearly $34 \%$ of national production, i.e., $15 \%$ of world output, is greater than the Cameroon's cocoa production (5th world cocoa producer) (Tano, 2012).

In this region, the production of food crops is very dynamic also. When the first non-indigenous people arrived and settled in the south-west area, the food crop productions have noticeably increased. These people grew commonly crops that they are used to consuming. A major part of national foodstuffs production, estimated to 8.9 million tons in 1999, is realized in the south-west Côte d'Ivoire (Sangaré, 2014).

Data collection took place through personal interviews conducted by research assistants. In these interviews, respondents give some information to fill in the questionnaire. This questionnaire was structured into four parts. The first elicited information concerning the individuals' social, economic and demographic characteristics. It further obtained information about household composition. The second part elicited information about the characteristics of farms. The third part elicited information to assess individual attitudes towards forest conservation and their sensitive to the variations of food price. The fourth part consisted of a description of the elicitation of individual's valuation of alternative management strategies through the construction of a contingent market. This method consists to elicit values that individuals assign to unpriced goods and services. This part also includes questions to determine why people decided to yield ground or not for forest conservation. It also provided information to identify protest responses. Finally, interviewers completed this part with information about the interview characteristics as well as their evaluation of the plausibility of the valuation scenarios for the individuals. This study used a two-stage random sampling technique. The first stage was the purposive selection of the villages in the southwest Cote d'Ivoire. The agglomerations located in the outlying areas of the National Park of Taï, have been regrouped in two categories: the first concerns the villages located in the west area of NPT in the department of Guiglo and the second includes those that are located in the east area of NPT in the department of Soubré. The second stage involved selection of investigated households by using a well-known sampling method. We tried to have a representative sampling by covering the maximum of the various rural communities living in this study area.

The sample has been selected among households settled in the vicinity of National Park of Taï. This park is a public forest area with about 5,364 km-square which became world-wide patrimony of UNESCO in 1988. Some localities, such as Taï and Daobly, are nearest the boundary of Liberia. The interviews were conducted by approaching respondents in their farms and their homes in September 2010 and June 2011; and, because it involved face-to-face interviews the response rate was nearby $95 \%$. Thus, two departments and eight villages have been visited during this survey. The choice of the visited localities and any given individual as respondent was random. The heads of households who have been selected are 508 in number by reason of 331 in the department of Soubré and 177 in the department of Guiglo (see Appendix A1). Because the population is not evenly distributed in the surroundings of NPT of course, we have chosen to select most of respondents among people living in the east of NPT (65.16\% of the sample), while less respondents among those living in the west of this park (34.84\%). This discrepancy in farmer number by visited region is explained by the divergence of forest cover ratio. Indeed this ratio equals $36.5 \%$ in west area of NPT against $14 \%$ in east area of this park (OIPR, 2006).

\subsection{The Empirical Model}

For a sample of 508 respondents settled in the south-west Côte d'Ivoire (see Appendix A1), we try to model the farmer behavior through the probability that a farmer decides to adhere to the reforestation project. So we use a binary-choice model in which the response variable is coded as 1 or 0 . We assume that the response of the farmer characterized by a dependent variable $y$ takes one of two values. Let us assume that:

$$
y=\left\{\begin{array}{lrr}
1 & \text { with probability } & p_{i} \\
0 & \text { with probability } & 1-p_{i}
\end{array}\right.
$$

We consider $U_{i 1}$ as utility of individual $i$ if the latter chooses to adhere to the project and $U_{i 0}$ his utility otherwise. These utility levels are not directly observed, they depend on socio-economic characteristics such as gender, age, occupation, residence, cultivated land, ethnic group and some specific characteristics of each 
alternative. To simplify, we assume that the utility levels $U_{i 1}$ and $U_{i 0}$ are explained by a linear model where causal factors are gathered in a set of variables called $X$.

$$
\begin{aligned}
& U_{i 1}=a_{1}+a_{11} x_{i 1}+a_{12} x_{i 2}+\cdots+\varepsilon_{i 1} \\
& U_{i 0}=a_{0}+a_{10} x_{i 1}+a_{20} x_{i 2}+\cdots+\varepsilon_{i 0}
\end{aligned}
$$

where $\varepsilon_{i 1}$ and $\varepsilon_{i 0}$ are the error terms.

The utility levels are not the observable variables, and the gap between $U_{i 1}$ and $U_{i 0}$ is a latent variable. The decision rule is as follows: individual chose to participate to the project if $U_{i 1}>U_{i 0}$. Assume that $P_{i}$ the probability that the individual $i$ chooses to participate to the forest restoration.

$$
\begin{gathered}
P_{i}=\operatorname{Pr}\left(y_{i}=1\right)=\operatorname{Pr}\left(U_{i 0}<U_{i 1}\right) \\
=\operatorname{Pr}\left[\varepsilon_{i 0}-\varepsilon_{i 1}<\left(a_{1}-a_{0}\right)+x_{i 1}\left(a_{11}-a_{10}\right)+x_{i 2}\left(a_{21}-a_{20}\right)+\cdots+x_{i n}\left(a_{n 1}-a_{n 0}\right)\right] \\
P_{i}=\operatorname{Pr}\left(\varepsilon_{i} \leq x_{i}^{\prime} \beta\right)=F\left(x_{i}^{\prime} \beta\right)
\end{gathered}
$$

with $\mathrm{F}$ represents the distribution function, $x_{i}^{\prime}=\left(\begin{array}{lllll}1 & x_{i 1} & x_{i 2} & \ldots & x_{i n}\end{array}\right)$ the vector of explanatory variables, $\varepsilon_{i}$ is a random effect equal to $\varepsilon_{i 0}-\varepsilon_{i 1}$, and $\beta$ the vector of estimate parameters:

$$
\beta=\left(\begin{array}{c}
a_{1}-a_{0} \\
a_{11}-a_{10} \\
\ldots \\
a_{n 1}-a_{n 0}
\end{array}\right)=\left(\begin{array}{c}
\beta_{1} \\
\beta_{2} \\
\ldots \\
\beta_{n}
\end{array}\right)
$$

As a general principle in a binary choice model, the individuals are supposed to have the choice between two possibilities. We attempt to model the probability of choice among these alternatives. Thus, the farmer decision represented by the variable could take two values 0 or 1 . By noting $P_{i}$ the probability that $y_{i}$ equal to 1 , we note:

$$
P_{i}=\operatorname{Pr}\left(y_{i}=1\right)=F\left(x_{i}^{\prime} \beta\right)
$$

The fact that the probability is included between 0 and 1 , consequently the model must verify the two following conditions:

$$
\begin{aligned}
& \lim _{x_{i}^{\prime} \beta \rightarrow+\infty} \operatorname{Pr}\left(y_{i}=1\right)=1 \\
& \lim _{x_{i}^{\prime} \beta \rightarrow-\infty} \operatorname{Pr}\left(y_{i}=1\right)=0
\end{aligned}
$$

\subsection{Analytical Method}

An OLS regression of $y_{i}$ on the vector $X$ cannot be used because this method ignores the discreteness of the dependent variable and does not constrain predicted probabilities to be between zero and one (Cameron \& Trivedi, 2005). Probit model is one of more appropriate models for binary outcomes. Using discrete dependent variable which cannot be modeled by linear regression, this model requires more computational effort to fit and is harder to interpret (Baum, 2006). And the best analytical method is the maximum likelihood estimation (MLE) [for mathematical demonstrations see Caderot et al. (2009, pp. 408-413) or Fomby (2010)].

Taking account these considerations, we formulate the following empirical model:

$$
\begin{gathered}
\text { decis }_{i}=\alpha_{0}+\alpha_{1} \text { age }_{i}+\alpha_{2} \text { liter }_{i}+\alpha_{3} \text { ethngr }_{i}+\alpha_{4} \text { marsta }_{i}+\alpha_{5} \text { landow }_{i}+\alpha_{6} \text { wtfarm }_{i}+\alpha_{7} \text { credit }_{i} \\
+\alpha_{8} \text { agritra }_{i}+\alpha_{9} \text { of }_{\text {income }}+\alpha_{10} \text { resarea }_{i}+\varepsilon_{i}
\end{gathered}
$$

where the indicator variable decis is set to zero for the farmer against the project of reforestation and to one for those reporting their adhesion to this project.

\subsection{Description and Justification of the Used Variables, Expected Signs of Their Coefficients}

The used variables in the estimation of Probit model are described and justified individually. Indeed, the results of the studies quoted in previous section allowed listing a set of explicative variables being able to affect the decision of farmers. The expected signs of the coefficients of these variables and their potential impacts on farmer decisions are presented in the next table. 
Table 1. Description of used variables

\begin{tabular}{|c|c|}
\hline Variables & Description \\
\hline decis & $\begin{array}{l}\text { The dependent variable reflects a situation of binary choice by representing the decision of household head (HH) } \\
\text { concerning the project of forest restoration. It equals to } 1 \text { if the response is yes and } 0 \text { otherwise. }\end{array}$ \\
\hline literacy & $\begin{array}{l}\text { This represents the educational level attained by the household head (HH). It takes the value } 1 \text { if } \mathrm{HH} \text { is a well-read } \\
\text { man (a well-read woman) and } 0 \text { otherwise. The fact that the } \mathrm{HH} \text { is illiterate decreases the probability to accept of } \\
\text { the reforestation project. }\end{array}$ \\
\hline ethnic group & $\begin{array}{l}\text { This variable describes two ethnic groups: the indigenous group and the non-indigenous group. This dummy } \\
\text { variable takes the value } 1 \text { if } \mathrm{HH} \text { belongs effectively to the native population and } 0 \text { otherwise. }\end{array}$ \\
\hline marsta & $\begin{array}{l}\text { This is a dummy variable which reflects the marital status of respondent. It takes the value } 1 \text { if } \mathrm{HH} \text { is married or } \\
\text { common-law and } 0 \text { otherwise. The fact that the interviewee is married or a common-law decreases the probability } \\
\text { to accept of this latter. }\end{array}$ \\
\hline Age & $\begin{array}{l}\text { The age of the respondents is measured in years. This variable is categorized in two age-groups: } 17 \text {-to- } 45 \text {-year-old } \\
\text { and } 45 \text {-to- } 85 \text {-year-old. The individuals, belonging to the } 17 \text {-to- } 45 \text {-year-old group, are supposed to have some } \\
\text { probabilities higher relative to the individuals of the other age-group. This category of persons thinks they could fit } \\
\text { into others sectors of economic activity by reason of their youth. As to the age-group of } 45 \text {-to- } 88 \text {-year-old, these } \\
\text { persons have family and social responsibilities such as they are unable to yield ground in a proportion higher than } \\
\text { the one of the previous age-group. }\end{array}$ \\
\hline landow & $\begin{array}{l}\text { This describes the status of landowner of the household head. It is a dummy variable which takes the value } 1 \text { if } \mathrm{HH} \\
\text { is landowner and } 0 \text { otherwise. The status of landowner is supposed to affect positively the decision of the HH. }\end{array}$ \\
\hline wtfarm & $\begin{array}{l}\text { This is a dummy variable which measures the worker status of the respondent. It takes the value } 1 \text { if the household } \\
\text { head is a whole-time farmer and } 0 \text { otherwise. The whole-time farmer are supposed to have a weak probability to } \\
\text { accept the forest restoration project relative to the others peasants. }\end{array}$ \\
\hline credit & $\begin{array}{l}\text { This dummy variable captures the access to credit. It takes the value } 1 \text { if the farmer has access to credit and } 0 \\
\text { otherwise. The farmers, who have access to loan, have a probability to yield ground higher than the one of others. }\end{array}$ \\
\hline agritra & $\begin{array}{l}\text { This is a dummy variable which takes the value } 1 \text { if the household head has benefited of an agricultural training } \\
\text { supplied by one of the technical services of Ministry of agriculture and } 0 \text { otherwise. Agricultural formation is } \\
\text { supposed to improve the productivity of farmers and could increase the probability to yield ground. }\end{array}$ \\
\hline $\begin{array}{l}\text { out-farm } \\
\text { income }\end{array}$ & $\begin{array}{l}\text { This dummy variable gives information about the out-farm income of the household head. It takes the value } 1 \text { if } \\
\text { this one (or another member of family) receives an income from another economic activity and } 0 \text { otherwise. The } \\
\text { household heads receiving this type of income are supposed to have a higher probability to yield ground } \\
\text { comparatively to the others household heads. }\end{array}$ \\
\hline resarea & $\begin{array}{l}\text { This is a dummy variable which indicates the household's residence area relative to National Park of Taï (NPT). It } \\
\text { takes the value } 1 \text { if the household inhabits in east area of NPT and } 0 \text { if the household inhabits in west area of this } \\
\text { park. The fact that the household lives in east area is assumed to affect positively the decision of the grower. }\end{array}$ \\
\hline
\end{tabular}

Source: Author's description.

\section{Results and Discussion}

Traditionally, any farmer with land sizes $\leq 2$ ha is considered as a smallholder. These farmers belonging to this category have low endowments of land as well as other factors such as capital but tend to be well endowed with labor (Birthal et al., 2013). But, according to survey data, the average cultivated land reaches 5.88 ha in export agriculture and 1.15 ha in food-crop agriculture. The agricultural activities practiced in the South-West are dominated by the crop of cocoa and the family production units. The survey results revealed only $15 \%$ of the respondents are farmers with land sizes $\leq 2$ ha. While if we consider as small farmer each landowner with land size $\leq 5$ ha because of the characteristics of export agriculture which is practiced generally on large land, the percentage of small farmers becomes $50.40 \%$. These results show that Ivorian agriculture is widely dominated by smallholders. It is observed that a high proportion of respondents $(89.96 \%)$ are landowners of their land areas cultivated.

The average size of households is about 10 individuals. Male-headed households are numerous in the sample than female-headed counterpart. Indeed, the first represent about $94.29 \%$ and the last $5.71 \%$ of the sample. Respondents are respectively at $60.63 \%, 22.24 \%, 16.14 \%$ and $0.98 \%$ of no education, primary, secondary and university education levels. As to ethnicity, it is remarked that the foreigners represent the largest ethnic group accounting for about $42.91 \%$ of the surveyed farmers. This was followed by the non-indigenous group (41.73\%) and the indigenous group (15.35\%).

Numerous are the farmers who practice the double-cropping. This category of farmers represents about $75.59 \%$ of the respondents. And a large part of the respondents practice the agricultural activity as a whole-time work. Also, diversification by farmers is observed toward high-value crops (cocoa, coffee, palm grove and particularly rubber) with a view to raise their farm incomes significantly. Consequently, it leads a detrimental decrease of 
food crops production.

Elsewhere, survey data reveal that about $58.66 \%$ of household heads belong to the 17 -to-45-year-old group. Thus there are $31.10 \%$ and $10.24 \%$ of the surveyed individuals respectively in the 45 -to-65-year-old group and the 65 -to-88-year-old group. The average age of surveyed farmers is estimated to be 43 years, while that the median age is 42 years. Most of the agricultural activities require a lot of strength and energy. With more than half of the surveyed persons belonging to the 17-to-45-year-old group, we can suppose evidently that the phenomenon of deforestation will continue to accelerate. Indeed, these farmers are likely to possess the necessary strength to carry out these operations. Survey data have also shown that the membership to the farm co-ops explains the decision of household head regarding the acceptance of the forest restoration policy. Estimates have indicated that more than half of the surveyed reported be members of these co-ops.

Moreover, as regards contacts with agricultural development agencies, it is observed that about $83.66 \%$ of surveyed farmers are in relation with the agricultural management structures on the one hand, and that nearly $34.25 \%$ of these farmers have received agricultural training on the other hand. Only $23.62 \%$ of farmers have previously had access to credit. Despite the proliferation of mutual aid group in almost totality of Ivorian communities, particularly in those who live in rural areas, it is observed that only few household heads are members of these groups.

Also, survey data reveal that nearly $70.08 \%$ of the respondents are opposed in a foreseeable future to the extension of the forest areas to the detriment of their cultivated areas. To understand the farmers' perception concerning the forest preservation, it is necessary to analyze the main reasons put forward in order not to yield ground (see next Table).

The answers to the attitudinal questions, which were included to assess the individual's perceptions regarding the necessity of the forest restoration, reveal that they perceived the harsh lack of farmland in the studied area and the significant contribution of forest resources to agricultural productivity. But only $29.92 \%$ of the respondents are willing to yield a parcel of their cropland for the forest restoration. As to the others respondents who are opposed to the project, they give several reasons to justify their decisions (see Table 2).

Table 2. Main causes of the refusal to contribute to the forest restoration

\begin{tabular}{lll}
\hline Main reasons & Responses & Percentage \\
\hline There is a harsh lack of farmland in the region & 264 & 74 \\
I am not the owner of my croplands & 21 & 06 \\
I have nothing to do outside of agriculture & 47 & 13 \\
The croplands are the property of my family and must be left to our descendants & 18 & 05 \\
Other reasons & 06 & 02 \\
\hline Total & $\mathbf{3 5 6}$ & $\mathbf{1 0 0}$ \\
\hline
\end{tabular}

Source: Author's calculation from field data.

Of all reasons described in the previous table, the rarefaction of forest area is mainly advanced by the farmers to explain their refusal of the reforestation policy. Then, there are respectively the incapability to find another job outside agriculture, the absence of property rights on the cultivated areas and the reason for leave a legacy to the descendants.

In order to understand the reasons for this discrepancy in the willingness to accept of farmers, an empirical estimate is conducted through a simple probit model. The estimation results allow identifying the main explanatory variables of farmer participation to the restoration of the forest. Thus, we notice that the farmer decision is affected by the age, the ethnic group, the fact to have benefit of an agricultural training, the access to credit and the residence area of his household. The values and the signs of coefficients of the explanatory variables are presented in the next table. 
Table 3. Empirical results of the simple probit model

\begin{tabular}{llcc}
\hline Variables & Coefficients & P-value & Marginal effects \\
\hline Literacy & .119 & 0.381 & .040 \\
Marital status & .134 & 0.480 & .047 \\
Age & .276 & $0.026^{* *}$ & $.094^{* *}$ \\
Whole-time farmer & .062 & 0.632 & .021 \\
Out-farm income & .262 & 0.262 & .083 \\
Ethnic group & .494 & $0.018^{* *}$ & $.150^{* *}$ \\
Agricultural training & .270 & $0.045^{* *}$ & $.089^{* *}$ \\
landow & .063 & 0.752 & .021 \\
Credit & .307 & $0.042^{* *}$ & $.099^{* *}$ \\
Residence area & .420 & $0.006^{* * *}$ & $.147^{* * *}$ \\
Constant & -.379 & 0.182 & \\
\hline Number of observations $=508 ;$ LR chi2(14) $=32.61 ;$ Prob $>$ chi $=0.000$ & \\
Log likelihood = -293.674; Pseudo R2 $=0.052$ & & \\
ficant at $1 \%{ }^{* *}$ significant at $5 \%{ }^{*}$ significant at $10 \%$. & \\
's calculation.
\end{tabular}

The estimate results allow making some remarks. Indeed, estimates reveal that only five of the explicative variables, age, ethnic origin, agricultural training, access to credit and household's residence area, are significant. These variables are positively associated with the acceptance of forest restoration. Also, the improvements in farmer productivity and agricultural performance appear to reduce the demand for more forest clearance. Elsewhere, estimate results indicate that, in the farmers' community, the young people are more willing to adhere to the project of forest restoration relative to the others. Indeed, the fact to be a young farmer (i.e., being from the group of 17-to-45-year-old) increases the probability of acceptance of the project of forest restoration by 0.0932 . As mentioned in the study of Moon et al. (2002), it is observed that age affects the willingness to pay of the respondents towards the environmental goods. Similarly, the fact of being from non-indigenous group decreases the probability to accept the project by 0.1528 529. Indeed, with regard to ethnic membership, the project of forest restoration was found to be slightly more accepted by the household whose the head is native from the southwest comparatively to the households whose the head is foreigner to the region (see Appendix A2). As to the fact to have access to credit, we remark that it has significant effect on the probability of acceptance. The farmers which have access to credit are more fitted to adhere to the forest restoration project than the others with a probability of 0.0998133 . Elsewhere, the fact to benefit an agricultural training increases the probability of adhesion to the project of the forest restoration by 0.0898 182. Finally, the results showed that the forest depletion increases the probability of acceptance by 0.150168 . This result shows the farmers settled in the study area where forest area is plentiful are more willing to adhere to the project of forest restoration relative to those which are living in the region weakly endowed with forest resource. As shown in the study of Lera-López et al. (2012) with populations living near roads who are willing to pay more to reduce air and noise pollution, we found in this study that the respondents living in the eastern area of the park (who are more affected by the environmental problem), are those who are willing to accept the reforestation policy.

Besides, the empirical results show that the farmers' decision is not explained by the following variables: marital status, literacy, whole-time farmer, out-farm income, and landowner. Concerning the out-farm income, we note that this one did not have statistically significant effects on the probability to accept the project of forest restoration. Thus, respondents which receive an income obtained outside agriculture are not more willing to accept than those deprived of this type of income. While this result is contrary to what we expected, a considerable number of studies on contingent valuation of environmental goods, and particularly the study of Moon et al. (2002), have reported the insignificant effect of income on WTP.

To justify the insignificant effect of landowner's status on the decision of farmer, we could put forward the unlawful occupation of state forests (classified forests, national reserves and parks) that is in vogue in the southwest Côte d'Ivoire. The forest areas located in this part of the country are seriously degraded. It is estimated that about $25 \%$ of the national production of cocoa is realized in the protected areas (parks, reserves, and classified forests), in large part in those that are located in the southwest Côte d'Ivoire (Sangaré, 2017).

Against all expectations, it is observed that the schooling of the household heads do not contribute significantly to explain their decisions of participation to the policy of forest restoration. One plausible explanation is that the educated farmers may be more aware of environmental problems comparatively to the others farmers. Indeed, the uneducated farmers don't evaluate exactly the risks related to the forests degradation. 
Besides, empirical estimates have highlighted some discrepancies between the probabilities to contribute to forest restoration across the western and eastern peripheries of National Park of Taï. This fact could offer useful insights into understanding environmental differences between the two areas. For these reasons, a useful comparison must be made between these areas. A selection of socioeconomic characteristics of the farmers was examined and their variations between the two visited districts under considerations established. On the whole, we observe the results described in Table 4.

Table 4. Comparison between the west area and the east area of the study area

\begin{tabular}{llll}
\hline Variables & West area & East area & t-test \\
\hline Average age (years) & 42.59 & 43.58 & -0.809 \\
Household size (persons) & 9.06 & 10.46 & $-2.485^{* * *}$ \\
Farming experience (years) & 11.30 & 20.54 & $-9.880^{* * *}$ \\
Average farm size (ha) & 7.12 & 7.49 & -0.464 \\
Average size of food-crop farms (ha) & 1.63 & 1.26 & $2.305^{* *}$ \\
Average size of cash-crop farms (ha) & 5.49 & 6.22 & -0.969 \\
Average length of residence (years) & 26.26 & 23.34 & $2.630^{* * *}$ \\
\hline
\end{tabular}

Source: computed from field data 2010/2011.

Comparative analysis of the socioeconomic characteristics between the two groups of smallholders indicates that there are significant differences in the estimated means for several variables. According to the student's test (T-test), two means are statistically different if the T-statistic is significant at the $5 \%$ level. Thus, the results of the T-test for equality of means displayed in Table 4 indicate that the variation between the two areas was not significant only for the variables such as average age, average farm size and average size of cash-crop farms. The contrary result is observed for the others variables (household size, farming experience, average size of food-crop farms; average length of residence) (see results of T-tests in Appendixes). As observed in the results of the T-test for equality of the means, we can consider that there is a significant difference between west and east areas.

As shortcomings to the estimates conducted in this paper, we can highlight the fact the probability of acceptance of the farmers might have been accounted for by some economic and environmental factors that are not or insufficiently captured in the model. These factors include education, contact with the agricultural development agencies, previous activity, household size, land quality, labour quality, disease, mutual aid group, and so on. In developing countries, it is commonly recognized that household size plays a significant role in farming, particularly in subsistence farming, where farmers rely on household members for the supply of the farm labour. So, household size might evidently explain the behavior of household head regarding the forest restoration.

Four of the variables, out-farm income, whole-time farmer, landowner, and literacy, were correctly signed. Also, it will be necessarily interesting to include in the analysis the variables regarding experience and traditional/improved technology used by the farmers and their perception of the deforestation. Indeed, Lera-López et al. (2012) observed in their study that the more environmentally aware individuals are willing to pay more to reduce some externalities. We can also suppose that the perception of individuals on deforestation could explain positively their adhesion to the large-scale reforestation.

\section{Conclusion and Policy Implications}

In Côte d'Ivoire, the issue of deforestation has come to centre stage. The economic consequences of deforestation and recent trends toward sustainable development have increased the pressure on policymakers to adhere to standards of sustainable agriculture in their duties.

This paper does not suggest that the reforestation policies are easy, nor does it suggest that Côte d'Ivoire has found an ideal model to limit deforestation, nor that such a model even exists. It aims to analyze the explanatory factors of the farmers' adhesion to the national program of forest development.

Our study site, the South-West Côte d'Ivoire, is an agriculture-dominated area, with the highest proportions of growers settled in this country. Thus, it is an excellent site to investigate the determinants of farmers' participation to any project of the restoration of forest areas. Our data, which were collected during September 2010 and June 2011, allow us to study the impact of socio-demographic and economic characteristics and geographic regions on their decision to contribute to this project and to explore implications of these findings for the reconstitution of Ivorian forest resources.

Descriptive statistics show that a larger part of farmers in this region is opposed to forest restoration policy. 
Nevertheless the findings highlight the need for the conservation and restoration of degraded forests. Most of farmers surveyed recognize that forest resources contribute significantly to grow their harvest. Also the farmers highlight the need to preserve the forest resources. But, only 29.92 percent of the investigated farmers accept, for a reason or another, to participate to forest rehabilitation.

This study found singularly that agricultural training, ethnic group, access to credit, the age of the head of household and the household's residence area play a very significant role in farmer's acceptance. The findings prove that agricultural training and access to credit are the main channels through which we might educate farmers on the reforestation project. Also, it is important to lead some policies for improving the farmer adhesion to the restoration of forest areas as well as fighting against deforestation. Indeed, restoring the degraded forest areas will bring numerous benefits to the economy of Côte d'Ivoire. Moreover, the carbon credit revenues could also be earned, bringing additional funds for forest conservation and livelihood improvement.

The problems of the forest restoration can be tackled in a variety of ways. Among them, a great importance might be given to a stronger policy framework which is imperative in bringing about improved farmer performance. These guidelines would include:

- Continuing to promote the adoption of best techniques of agricultural production. Particularly, the policymakers would promote the development and diffusion of modern high-yielding varieties of crops. This leads to the increase of farmers' productivity and the sensitive decrease of the forest degradation also. The co-ops might play an important role in this context.

- Strengthening the policy of employment creation in the sectors with low intensity in land. This allows to turn away young people from agricultural activities toward others activities less dangerous for the forest.

- Increasing the access of farmers to the improved seed. This action will decrease assuredly the quantities of cropland. Also Ivorian authorities must develop the changes in technology that would permit the double-cropping to replace the single-cropping.

This short survey of the literature on the deforestation in Côte d'Ivoire presented earlier in this study suggests several issues for further research. The further research should be conducted with data of a large-scale national survey.

\section{Acknowledgements}

I would like to thank CODESRIA for its small grant to the redaction of my thesis. This financial support was very helpful during data collection. I am also grateful to anonymous reviewers for their helpful input.

\section{References}

Barbier, E. B. (2010). Poverty, Development, and Environment. Environment and Development Economics, 1-26. https://doi.org/10.1017/s1355770x1000032x

Baum, C. F. (2006). An Introduction to modern Econometrics Using Stata. A Stata Press Publication, United States of America.

Birthal, P. S., Joshi, P. K., Roy, D., \& Thorat, A. (2013). Diversification in Indian Agriculture toward High-Value Crops: The Role of Small Farmers. Canadian Journal of Agricultural Economics, 61, 61-91. https://doi.org/10.1111/j.1744-7976.2012.01258.x

Cadoret, I., Benjamin, C., Martin, F., Herrard, N., \& Tanguy, S. (2009). Econométrie appliquée, Méthode-Applications-Corrigés (2eme édition). Edition de Boeck Université, Belgique.

Cameron, A. C., \& Trivedi, P. K. (2005). Microeconometrics, Methods and Applications. New York: Cambridge University Press. https://doi.org/10.1017/CBO9780511811241

Ehui, S. K., \& Hertel, T. W. (1989). Deforestation and Agricultural Productivity in the Côte d'Ivoire. American Journal of Agricultural Economics, 71(3), 703-711. https://doi.org/10.2307/1242026

Ehui, S.K., Hertel, T.W., \& Preckel, P.V. (1990). Forest Resource Depletion, Soil dynamics, and Agricultural Productivity in the Tropics. Journal of Environmental Economics and Management, 18, 136-154. https://doi.org/10.1016/0095-0696(90)90044-Y

FAO. (2012). State of the World's Forests. Rome.

Fomby, T. B. (2010). Lecture Notes on Binary Choice Models: Logit and Probit, Maximum Likelihood Estimation of Logit and Probit Models, Department of Economic SMU March, 2010. Retrieved from http://faculty.smu.edu/tfomby/eco5385/lecture/Logit\%20and\%20Probit\%20Notes.pdf 
Lamb, D., \& Gilmour, D. (2003). Rehabilitation and Restoration of Degraded Forests. Scientific Reports, 6(2), 773-776.

Lera-López, F., Faulin, J., \& Sánchez, M. (2012). Determinants of the willingness-to-pay for reducing the environmental impacts of road transportation. Transportation Research Part D, 17, 215-220. https://doi.org/10.1016/j.trd.2011.11.002

Madureira, L., Nunes, L. C., Borges, J. G., \& Falcão, A. O. (2011). Assessing forest management strategies using a contingent valuation approach and advanced visualisation techniques: A Portuguese case study. Journal of Forest Economics, 17, 399-414. https://doi.org/10.1016/j.jfe.2011.04.001

Ministry of Planning and Development. (2012). Plan National du Développement 2012-2015. République de Côte d'Ivoire.

Ministry of Planning and Development. (2014). Preliminary results of 2014 Census, République de Côte d'Ivoire.

Moon, W., Florkowski, W. J., Brückner, B., \& Schonhof, I. (2002). Willingness to Pay for Environmental Practices: Implications for Eco-Labeling. Land Economics, 78(1), 88-102. https://doi.org/10.2307/3146925

OIPR. (2006). Plan d'aménagement et de gestion du Parc national de Taï, Office Ivoirien des Parcs et Réserves, l'environnement, Ministère des Eaux et Forêts.

Raboteur, J., \& Rodes, M. F. (2006). Application de la Méthode d'Evaluation Contingente aux récifs coralliens dans la Caraïbe: Etude appliquée à la zone de Pigeon de la Guadeloupe. La Revue électronique en Sciences de l'Environnement VertigO, 7(1), 1-17. Retrieved from http://www.guadeloupe.developpement-durable.gouv.fr/IMG/pdf/vertigovol7no1_Raboteur_et_Rodes.pdf

Sangaré, M. (2011). Effets de la raréfaction des espaces cultivables sur les niveaux de productions agricoles dans le Sud-Ouest de la Côte d'Ivoire. Document de recherche.

Sangaré, M. (2014). Déforestation et Agriculture en milieu rural ivoirien (Thèse unique, Université Félix Houphouët-Boigny de Cocody-Abidjan).

Sangaré, M. (2017). Analyse économique de la Restauration des Aires Protégées en Côte d'Ivoire: Cas du Parc National de Taï. European Scientific Journal, 13(1, 2 \& 3).

Shechter, M. (2000). Valuing the environment. In H. Folmer \& H. L. Gabel (Eds.), Principles of Environmental and Resource Economics, New Horizons in Environmental Economics (2nd ed., pp. 72-103). Cheltenham, UK: Edward Elgar Publishing Limited.

Stessens, J., \& Dao, D. (2006). Côte d'Ivoire: Profil des marchés pour les évaluations d'urgence de la sécurité alimentaire. Katholieke Universiteit Leuven, Programme Alimentaire Mondial, Service de l'Evaluation des besoins d'urgence (ODAN).

Tano, A. M. (2012). Crise cacaoyère et Stratégies des producteurs de la Sous-Préfecture de Méadji au Sud-Ouest ivoirien. Thèse en vue de l'obtention du Doctorat de l'Université Toulouse 2 Le Mirail (UT2 Le Mirail).

Wasikama, T. M. C. (1998). Utilisation alternative des terres: une analyse économique de la préservation des forêts tropicales primaires (cas du parc national de TAÏ, SUD-OUEST de la Côte d'Ivoire). (Thèse de Doctorat $3^{\text {eme }}$ Cycle, Université de Cocody-Abidjan, CIRES).

Westerberg, V. H., Lifran, R., \& Olsen, S. B. (2010). To restore or not? A valuation of social and ecological functions of the Marais des Baux wetland in Southern France, Ecological Economics, 69, 2383-2393. https://doi.org/10.1016/j.ecolecon.2010.07.005 


\section{Appendix A1}

The Distribution of Respondents according to Visited Localities

\begin{tabular}{lllll}
\hline DISTRICTS & SUB-PREFECTURES & VILLAGES & RESPONDENTS & TOTAL \\
\hline \multirow{4}{*}{ SOUBRE } & Buyo & Buyo & 131 & \multirow{2}{*}{331} \\
& & Konédougou & 59 & \\
\cline { 2 - 4 } & Oupoyo & Walèbo & 65 & \\
\cline { 2 - 5 } & Meagui & Kragui & 14 \\
& & Pogréagui & 62 & \multirow{2}{*}{177} \\
\hline \multirow{2}{*}{ GUIGLO } & \multirow{2}{*}{ Taï } & Taï & 77 & 508 \\
& & Daobly & 41 & \\
\hline TOTAL & 4 & Zagné & 59 & 508 \\
\hline
\end{tabular}

Source: Survey Data.

\section{Appendix A2}

\section{Description of the Explicative Variables}

\begin{tabular}{|c|c|}
\hline Variables & Description \\
\hline Decis & $=1$ if the response of $\mathrm{HH}$ is yes and 0 otherwise \\
\hline \multicolumn{2}{|c|}{ Socio-demographic variables } \\
\hline Age & $=1$ if the $\mathrm{HH}$ belongs to the class $[17-45[$ and 0 otherwise \\
\hline Literacy & Academic standard of the $\mathrm{HH}$ (1: well-read and 0 otherwise) \\
\hline Marital status & Marital status of household head (1: married and $0:$ no) \\
\hline Ethnic group & $=1$ if the $\mathrm{HH}$ is indigenous and 0 otherwise \\
\hline Landow & $=1$ if the $\mathrm{HH}$ is landowner and 0 otherwise \\
\hline \multicolumn{2}{|c|}{ Economic variables } \\
\hline wtfarm & $=1$ if the $\mathrm{HH}$ is a whole-time farmer and 0 otherwise \\
\hline Credit & $=1$ if the Household has access to credit and 0 otherwise \\
\hline Agritra & $=1$ if the $\mathrm{HH}$ is payee of an agricultural training and 0 otherwise \\
\hline Out-farm income & $=1$ if the household receives an out-farm income and 0 otherwise \\
\hline \multicolumn{2}{|c|}{ Environmental variables } \\
\hline resarea & $=1$ if the household lives in east area of NPT and 0 in west area \\
\hline
\end{tabular}
Source: Author's description.

\section{Appendix A3}

\section{General Statistics}

\begin{tabular}{lllll}
\hline Variables & Mean & Standard-error & Minimum & Maximum \\
\hline Decis & .7007874 & .4583645 & 0 & 1 \\
Socio-demographic variables & & & \\
Age & 43.24 & 13.1724 & 17 & 88 \\
Literacy & .3897638 & .4881773 & 0 & 1 \\
Marital status & .8818898 & .3230567 & 0 & 1 \\
Ethnic group & .1535433 & .3608658 & 0 & 1 \\
Landow & .8996063 & .3008204 & 0 & 1 \\
Economic variables & & & & 1 \\
wtfarm & .3562992 & .4793771 & 0 & 1 \\
Credit & .2362205 & .4251779 & 0 & 1 \\
Agritra & .3425197 & .4750201 & 0 & 1 \\
Out-farm income & .0905512 & .2872527 & 0 & 1 \\
Environmental variables & & & & \\
resarea & .6515748 & .4769411 & 0 & \\
\hline
\end{tabular}

Source: Author's calculation from field data. 


\section{Appendix A4}

\section{Analysis of Correlations between the Different Variables}

\begin{tabular}{|c|c|c|c|c|c|c|c|c|c|c|}
\hline I & decis & marsta & wtfarm & ofinc & ag_1 & eth_1 & landow & iteracy & agritra & loan \\
\hline decis | & 1. 0000 & & & & & & & & & \\
\hline marsta & 0.0139 & 1. 0000 & & & & & & & & \\
\hline wtfarm | & 0.0373 & -0.0079 & 1.0000 & & & & & & & \\
\hline of inc | & 0.0414 & -0.0333 & 0.2379 & 1.0000 & & & & & & \\
\hline ag_1 | & 0.0984 & -0.1681 & 0.0540 & -0.0212 & 1. 0000 & & & & & \\
\hline eth_1 & 0.0756 & -0.0979 & $0.0 \leq 80$ & 0.2271 & 0.0187 & 1. 0000 & & & & \\
\hline landow & 0.0535 & 0.0604 & 0.0160 & 0.0826 & -0.1277 & 0.0878 & 1.0000 & & & \\
\hline 1iteracy & 0.0903 & -0.0702 & 0.1808 & 0.1276 & 0.1388 & 0.3426 & 0.0521 & 1.0000 & & \\
\hline agritra & 0.1274 & 0.0713 & 0.0260 & -0.0109 & -0.0216 & -0.0082 & 0.1721 & 0.0781 & 1.0000 & \\
\hline loan & 0.1205 & 0.0168 & 0.0411 & 0.0345 & 0.0036 & -0.0569 & 0.0470 & 0.0497 & 0.1455 & 1.0000 \\
\hline resarea & 0.0816 & 0.0524 & -0.1547 & -0.3739 & -0.0062 & -0.5022 & 0.0719 & -0.2119 & 0.1447 & 0.1343 \\
\hline
\end{tabular}

Source: Author's calculation.

. ttest aneprai1_1, by (loca) 1

Two-sample $\mathrm{t}$ test with equal variances

\begin{tabular}{lllllll}
\hline Group & Obs & Mean & Std. Err. & Std. Dev. & [95\% Conf. & Interval] \\
0 & 177 & 11.30508 & .6833632 & 9.091556 & 9.956444 & 12.65373 \\
1 & 331 & 20.54381 & .5778584 & 10.51321 & 19.40706 & 21.68056 \\
combined & 508 & 17.3248 & .4861267 & 10.95674 & 16.36973 & 18.27987 \\
diff & & -9.238722 & .9350464 & & -11.07577 & -7.40167 \\
\hline diff $=$ mean $(0)$ - mean $(1) ; \mathrm{t}=-9.8805$ & & & \\
Ho: diff $=0 ;$ degrees of freedom $=506$ & & \\
Ha: diff $<0 ;$ Ha: diff $!=0 ;$ Ha: diff $>0$ & & & \\
$\operatorname{Pr}(\mathrm{T}<\mathrm{t})=0.0000 ; \operatorname{Pr}(|\mathrm{T}|>|\mathrm{t}|)=0.0000 ; \operatorname{Pr}(\mathrm{T}>\mathrm{t})=1.0000$ & & \\
\hline
\end{tabular}

. ttest supv, by (loca)

Two-sample $\mathrm{t}$ test with equal variances

\begin{tabular}{lllllll}
\hline Group & Obs & Mean & Std. Err. & Std. Dev. & [95\% Conf. & Interval] \\
0 & 177 & 42.59322 & 1.010581 & 13.4449 & 40.5988 & 44.58764 \\
1 & 331 & 43.5861 & .7162869 & 13.0317 & 42.17704 & 44.99517 \\
combined & 508 & 43.24016 & .5844309 & 13.1724 & 42.09195 & 44.38836 \\
diff & & -.9928824 & 1.226999 & & -3.403522 & 1.417757 \\
\hline diff $=$ mean $(0)$ - mean $(1) ; \mathrm{t}=-0.8092$ & & & \\
Ho: diff $=0 ;$ degrees of freedom $=506$ & & & \\
Ha: diff $<0 ;$ Ha: diff $!=0 ;$ Ha: diff $>0$ & & & \\
$\operatorname{Pr}(\mathrm{T}<\mathrm{t})=0.2094 ; \operatorname{Pr}(|\mathrm{T}|>|\mathrm{t}|)=0.4188 ; \operatorname{Pr}(\mathrm{T}>\mathrm{t})=0.7906$ & & & \\
\hline
\end{tabular}

. ttest supi, by (loca)

Two-sample $t$ test with equal variances

\begin{tabular}{lllllll}
\hline Group & Obs & Mean & Std. Err. & Std. Dev. & [95\% Conf. & Interval] \\
0 & 177 & 163.0282 & 13.54627 & 180.2213 & 136.2942 & 189.7623 \\
1 & 331 & 126.4502 & 9.062759 & 164.8825 & 108.6221 & 144.2782 \\
combined & 508 & 139.1949 & 7.591248 & 171.098 & 124.2807 & 154.1091 \\
diff & 36.5781 & 15.86484 & & 5.409034 & 67.74716 \\
\hline diff $=$ mean $(0)$ - mean $(1) ; \mathrm{t}=2.3056$ & & \\
Ho: diff $=0 ;$ degrees of freedom $=506$ & & \\
Ha: diff $<0 ;$ Ha: diff $!=0 ;$ Ha: diff $>0$ & & \\
$\operatorname{Pr}(\mathrm{T}<\mathrm{t})=0.9892 ; \operatorname{Pr}(|\mathrm{T}|>|\mathrm{t}|)=0.0215 ; \operatorname{Pr}(\mathrm{T}>\mathrm{t})=0.0108$ & & \\
\hline
\end{tabular}


. ttest totmena, by (loca)

Two-sample t test with equal variances

\begin{tabular}{lllllll}
\hline Group & Obs & Mean & Std. Err. & Std. Dev. & {$[95 \%$ Conf. } & Interval] \\
0 & 177 & 549.7175 & 78.21858 & 1040.631 & 395.3505 & 704.0846 \\
1 & 331 & 622.568 & 35.69135 & 649.3471 & 552.3567 & 692.7792 \\
combined & 508 & 597.185 & 35.81386 & 807.2033 & 526.8232 & 667.5469 \\
diff & & -72.85046 & 75.16924 & & -220.5327 & 74.83179 \\
\hline diff $=$ mean $(0)$ - mean $(1) ; \mathrm{t}=-0.9692$ & & \\
Ho: diff $=0 ;$ degrees of freedom $=506$ & & \\
Ha: diff $<0 ;$ Ha: diff $!=0 ;$ Ha: diff $>0$ & & & \\
$\operatorname{Pr}(\mathrm{T}<\mathrm{t})=0.1665 ; \operatorname{Pr}(|\mathrm{T}|>|\mathrm{t}|)=0.3329 ; \operatorname{Pr}(\mathrm{T}>\mathrm{t})=0.8335$ & & \\
\hline
\end{tabular}

. ttest sup, by(site)

Two-sample $t$ test with equal variances

\begin{tabular}{lllllll}
\hline Group & Obs & Mean & Std. Err. & Std. Dev. & {$[95 \%$ Conf. } & Interval] \\
0 & 177 & 9.067797 & .3773227 & 5.019952 & 8.323137 & 9.812456 \\
1 & 331 & 10.46828 & .3591625 & 6.534389 & 9.761741 & 11.17481 \\
combined & 508 & 9.980315 & .2698272 & 6.081596 & 9.450198 & 10.51043 \\
diff & -1.400481 & .5634328 & & -2.507437 & -.2935255 \\
\hline diff $=$ mean $(0)$ - mean $(1) ; \mathrm{t}=-2.4856$ & & & \\
Ho: diff $=0 ;$ degrees of freedom $=506$ & & & \\
Ha: diff $<0 ;$ Ha: diff $!=0 ;$ Ha: diff $>0$ & & & \\
$\operatorname{Pr}(\mathrm{T}<\mathrm{t})=0.0066 ; \operatorname{Pr}(|\mathrm{T}|>|\mathrm{t}|)=0.0133 ; \operatorname{Pr}(\mathrm{T}>\mathrm{t})=0.9934$ & & & \\
\hline
\end{tabular}

. ttest resid, by(site)

Two-sample $t$ test with equal variances

\begin{tabular}{lllllll}
\hline Group & Obs & Mean & Std. Err. & Std. Dev. & {$[95 \%$ Conf. } & Interval] \\
0 & 177 & 712.7627 & 79.33695 & 1055.51 & 556.1885 & 869.3369 \\
1 & 331 & 749.0181 & 38.20995 & 695.1692 & 673.8523 & 824.1839 \\
combined & 508 & 736.3858 & 37.16308 & 837.6132 & 663.3732 & 809.3984 \\
diff & & -36.25542 & 78.05683 & & -189.6108 & 117.1 \\
\hline diff $=$ mean $(0)$ - mean $(1) ; \mathrm{t}=-0.4645$ & & & \\
Ho: diff $=0 ;$ degrees of freedom $=506$ & & & \\
Ha: diff $<0 ;$ Ha: diff $!=0 ;$ Ha: diff $>0$ & & & \\
$\operatorname{Pr}(\mathrm{T}<\mathrm{t})=0.3213 ; \operatorname{Pr}(|\mathrm{T}|>|\mathrm{t}|)=0.6425 ; \operatorname{Pr}(\mathrm{T}>\mathrm{t})=0.6787$ & & & \\
\hline
\end{tabular}

. ttest resid, by(site)

Two-sample $t$ test with equal variances

\begin{tabular}{lllllll}
\hline Group & Obs & Mean & Std. Err. & Std. Dev. & [95\% Conf. & Interval] \\
0 & 177 & 26.26554 & 1.155208 & 15.36904 & 23.98569 & 28.54538 \\
1 & 331 & 23.34139 & .5286831 & 9.618546 & 22.30138 & 24.3814 \\
combined & 508 & 24.36024 & .5327095 & 12.00666 & 23.31365 & 25.40683 \\
diff & & 2.924147 & 1.111559 & & .7403081 & 5.107986 \\
\hline diff $=$ mean $(0)$ - mean $(1) ; \mathrm{t}=2.6307$ & & \\
Ho: diff $=0 ;$ degrees of freedom $=506$ & & \\
Ha: diff $<0 ;$ Ha: diff $!=0 ;$ Ha: diff $>0$ & & \\
$\operatorname{Pr}(\mathrm{T}<\mathrm{t})=0.9956 ; \operatorname{Pr}(|\mathrm{T}|>|\mathrm{t}|)=0.0088 ; \operatorname{Pr}(\mathrm{T}>\mathrm{t})=0.0044$ & & \\
\hline
\end{tabular}

\section{Copyrights}

Copyright for this article is retained by the author(s), with first publication rights granted to the journal.

This is an open-access article distributed under the terms and conditions of the Creative Commons Attribution license (http://creativecommons.org/licenses/by/4.0/). 